\title{
Limbah Batubara Sebagai Pembenah Tanah dan Sumber Nutrisi : Studi Kasus Tanaman Bunga Matahari (Helianthus Annus)
}

\author{
Coal Combustion Waste As Soil Amelioratnat and Source of \\ Nutrients : Case Study for Sunflower (Helianthus Annus)
}

\section{Rhazista Noviardi}

\begin{abstract}
ABSTRAK Penelitian ini dilakukan untuk mengkaji pemanfaatan limbah batubara sebagai pembenah tanah dan sumber nutrisi bagi tanaman bunga matahari (Helianthus Annus). Penelitian menggunakan Rancangan Acak Kelompok (RAK) pola faktorial yang terdiri dari dua faktor. Faktor pertama adalah rasio limbah batubara $(\%$ berat) yang terdiri dari 6 (enam) perlakuan yaitu $0,10,20,30,40$ dan 50\%. Faktor kedua adalah dosis kompos yang terdiri dari 3 (tiga) perlakuan yaitu 0, 400 dan 800 gram/pot. Kedua faktor tersebut dikombinasikan sehingga diperoleh 18 perlakuan dengan dua kali ulangan sehingga terdapat 36 pot percobaan. Pengaruh perbedaan perlakuan pada percobaan diuji dengan uji ANOVA pada taraf 5\%. Untuk mengetahui perbedaan antar perlakuan pada masing-masing faktor, dilakukan uji jarak berganda Duncan, pada taraf ketelitian 5\%. Hasil penelitian menunjukkan bahwa penambahan limbah batubara atau kompos pada tanah meningkatkan biomassa tanaman bunga matahari, namun bila keduanya dikombinasikan tidak berpengaruh terhadap biomassa tanaman. Penambahan limbah batubara 50\% (\% berat) atau kompos $800 \mathrm{~g} /$ pot menghasilkan biomassa tanaman bunga matahari tertinggi yaitu masing-masing sebesar $0,16 \mathrm{~kg}$ dan 0,14 kg bk (berat kering).
\end{abstract}

Kata Kunci: Amelioran, bunga matahari, kompos, limbah batubara, tanah.

$\begin{array}{ll}\text { Naskah masuk } & : \text { 12 April } 2012 \\ \text { Naskah selesai revisi } & : \text { 24 Oktober } 2012 \\ \text { Naskah siap cetak } & : \text { 20 Mei } 2013\end{array}$

Rhazista Noviardi

UPT. Loka Uji Teknik Penambangan

Jampang Kulon - LIPI

Email : noviardi72@yahoo.com
ABSTRACT This research was conducted to address the utilization of coal waste as soil ameliorant and source of nutrients for Sunflower (Helianthus Annus). This study used the Randomized Block Design (RBD) factorial pattern consisting of two factors. The first factor is the ratio of coal ash (\% of weight) consisting of 6 treatments, i.e. 0, 10, 20, 30, 40 and 50\%. The second factor is the dose of compost consisted of 3 treatments, i.e. 0, 400 and $800 \mathrm{~g} /$ pot. These two factors were combined to obtain 18 treatments with two replications, so there were 36 pot experiments. The effects of different treatments in the experiment were tested by ANOVA test at 5\% level. To understand the difference between treatments in each factor, Duncan multiple range tests were conducted at the level of accuracy of 5\%. The results showed that the addition of coal ash or compost to the soil increases the sunflower plant biomass, but when both were combined, no effects were noted on the plant biomass. The addition of $50 \% \mathrm{coal}$ ash (\% of weight) or compost $800 \mathrm{~g} /$ pot yielded the highest sunflower plant biomass that is 0.16 $\mathrm{kg}$ and $0.14 \mathrm{~kg}$ (dry weight) respectively.

Keywords: Ameliorant, sunflower plant, compost, coal ash, soil.

\section{PENDAHULUAN}

Bahan bakar fosil seperti batubara dan minyak bumi masih merupakan sumber energi utama di Indonesia. Kenaikan harga bahan bakar minyak menyebabkan banyaknya industri yang semula menggunakan bahan bakar minyak beralih ke batubara sebagai sumber energi untuk produksinya. Menurut Suyartono (2004), dengan kualitas tingkat produksi saat ini, batubara dapat menjadi sumber energi bagi Indonesia selama 
ratusan tahun. Cadangan batubara Indonesia saat ini sebesar 28 miliar ton atau sekitar 3\% dari total cadangan batu bara dunia. Sementara, total sumberdaya batubara Indonesia kini mencapai 161 miliar ton, meningkat dari status 2010 sebesar 105 miliar ton (Bisnis Indonesia, 4 Juni 2012). Penggunaan batubara pada proses produksi pada industri-industri di Indonesia diperkirakan semakin meningkat, sehingga dapat memberikan dampak negatif terhadap kualitas lingkungan.

Dampak lingkungan yang ditimbulkan dari meningkatnya penggunaan batubara dalam industri adalah berupa peningkatan jumlah limbah padat sisa pembakaran batubara yang yang termasuk kategori limbah bahan beracun dan berbahaya atau B3 dan memerlukan penanganan khusus. Dari pembakaran batubara dihasilkan sekitar 5\% polutan padat yang berupa abu terbang (fly ash) dan abu bawah (bottom ash), dimana sekitar 10-20\% adalah abu bawah dan sekitar $80-90 \%$ adalah abu terbang dari total abu yang dihasilkan (Wardani, 2008). Berdasarkan data Dinas ESDM Jawa Barat, sekitar 226 perusahaan yang tersebar di 10 Kabupaten/Kota memakai dan memproduksi limbah batu bara. Diperkirakan, pada tahun ini limbah batubara yang dihasilkan mencapai 3,5 juta ton, meningkat dari tahun 2009 yang mencapai 3,29 ton (Pikiran Rakyat, 10 Januari 2012).

Limbah batubara diperoleh dari sisa pembakaran batubara secara sederhana dengan corong gas dan menyebar ke atmosfer. Hal ini menimbulkan masalah lingkungan dan kesehatan, karena fly ash dan bottom ash dari tempat pembakaran batubara yang dibuang sebagai timbunan limbah batubara ini terdapat dalam jumlah yang besar. Oleh sebab itu diperlukan pengelolaan agar tidak menimbulkan masalah lingkungan seperti pencemaran udara, atau perairan dan penurunan kualitas ekosistem. Salah satu penanganan lingkungan yang dapat diterapkan adalah pemanfaatan limbah batubara untuk keperluan bahan bangunan teknik sipil. Namun, hasil pemanfaatan tersebut belum dapat dimasyarakatkan secara optimal karena berdasarkan PP. No. 85 tahun 1999 tentang pengelolaan limbah bahan berbahaya dan beracun (B3), fly ash dan bottom ash dikategorikan sebagai limbah B3 karena terdapat kandungan oksida logam berat yang akan mengalami pelindian secara alami dan mencemari lingkungan. Pemanfaatan limbah hasil pembakaran batubara menjadi paving block, batako dan lainnya didaerah Kabupaten Bandung dan sekitarnya baru menyerap sekitar $12 \%$ saja dari sekitar 500.000 ton pertahun, sehingga semakin lama limbah ini akan semakin menggunung (Sutomo dan Sofyan, 2008).

Berdasarkan permasalahan diatas, perlu dicari alternatif penggunaan lain limbah batubara untuk mengurangi penimbunan. Salah satu kemungkinan pemanfaatan adalah menggunakan limbah batubara sebagai pupuk tanaman. Dalam penelitian ini dilakukan perbandingan antara penambahan limbah batubara dan kompos pada tanah terhadap biomassa tanaman bunga matahari (Helianthus Annuus).

\section{TINJAUAN PUSTAKA}

Limbah padat batubara dari pabrik tekstil terdiri dari abu terbang (fly ash) dan abu bawah (bottom ash) yang merupakan sisa pembakaran yang tidak sempurna dari batubara. Jumlah limbah batubara yang dihasilkan dari proses pembakaran batubara bervariasi tergantung sumber dan kualitas batubara, tetapi biasanya berkisar antara $12 \%$ sampai dengan $16 \%$ dari batubara yang dibakar (Evangelou, 1996).

Secara kimia, abu batubara merupakan mineral aluminosilikat yang banyak mengandung unsurunsur seperti $\mathrm{Ca}, \mathrm{K}$, dan $\mathrm{Na}$ disamping juga mengandung sejumlah kecil unsur $\mathrm{C}$ dan $\mathrm{N}$. Bahan nutrisi lain dalam abu batubara yang diperlukan dalam tanah bagi tanaman diantaranya Boron (B), fosfor (P) dan unsur-unsur seperti $\mathrm{Cu}$, $\mathrm{Zn}, \mathrm{Mn}$, Mo dan Se. Umumnya abu batubara bersifat alkalis ( $\mathrm{pH}$ 8-12). Secara fisika, abu batubara memiliki ukuran partikel berukuran silt dan memiliki karakteristik kapasitas pengikat air dari sedang sampai tinggi (Damayanti, 2003).

Disamping mengandung unsur beracun, abu terbang juga mengandung unsur hara yang dibutuhkan tanaman. Beberapa hasil penelitian menunjukkan bahwa abu terbang dapat digunakan sebagai sumber dari kalium, fosfor, kalsium, magnesium, sulfur dan beberapa unsur hara mikro (Adriano dkk., 1980). Tanah yang diberi campuran $35 \%$ abu terbang dan limbah rumah tangga dengan perbandingan $1: 1 \mathrm{~V} / \mathrm{V}$ memberikan peningkatan hasil pada pertumbuhan 
tanaman. Sehingga dapat dikatakan bahwa abu terbang dan limbah rumah tangga memiliki potensi untuk pemanfaatan pada bidang pertanian (Wong dan Su, 1997).

Berdasarkan penelitian Marques (2008), pupuk organik (kompos dan pupuk kandang) dapat meningkatkan biomassa tanaman dan mengurangi pencucian (leaching) Zn pada tanah yang tercemar. Sementara itu, berdasarkan penelitian Rotkittikhun (2007) penambahan pupuk yang berasal dari kotoran babi meningkatkan pertumbuhan tanaman dan penyerapan logam timbal $(\mathrm{Pb})$ oleh tanaman Thysanolaena maxima (Roxb.) dan Vetiveria zizanioides (L.). Dalam penelitian ini, bunga matahari dipilih untuk menguji manfaat penambahan abu terbang pada tanah media tanamnya. Karakteristik tanaman dianalisa berdasarkan perbandingan biomassa tanaman yang ditanam pada media yang berbeda: dengan tambahan abu terbang atau tidak.

Bunga matahari (Helianthus Annus) merupakan tanaman cepat tumbuh dengan produksi biomassa yang tinggi dan memiliki banyak kegunaan yaitu sebagai tanaman hias, pakan ternak, penghasil minyak dan bahan pangan. jumlah total bobot kering semua bagian tumbuhan hidup. Biomassa tumbuhan bertambah karena tumbuhan menyerap karbondioksida (CO2) dari udara dan mengubah zat ini menjadi bahan organik melalui proses fotosintesis. Dalam mekanisme kehidupan bersama tersebut, terdapat interaksi yang erat baik diantara sesama individu penyusun vegetasi itu sendiri maupun organisme lainnya sehingga merupakan suatu sistem yang hidup dan tumbuh secara dinamis vegatasi, tanah dan iklim berhubungan erat dan pada tiap-tiap tempat mempunyai keseimbangan yang spesifik (Hamilton dan King, 1988).

\section{METODE PENELITIAN}

Bahan yang digunakan pada penelitian ini meliputi limbah batubara yang berasal dari pabrik tekstildi kawasan industri Leuwigajah, Cimahi. Adapun tanah yang digunakan diambil dari tanah di area Balai Penelitian Sayuran (Balitsa), Cikole-Lembang. Sedangkan bibit bunga matahari yang digunakan berumur \pm 6 minggu yang diperoleh dari daerah Cihideung, Lembang. Sebagai pembanding kami gunakan kompos yang diperoleh dari toko pertanian.

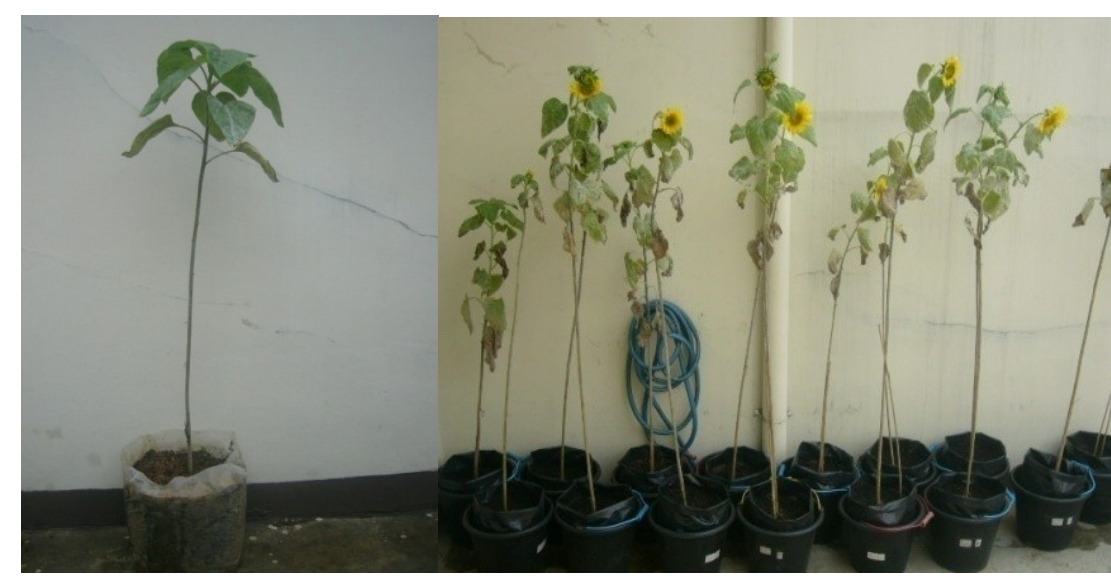

(a)

(b)

Gambar 1. (a) Bibit Tanaman Bunga Matahari. (b) Umur 8 Minggu Setelah Tanam.

Biomassa merupakan istilah untuk bobot hidup, biasanya dinyatakan sebagai bobot kering, untuk seluruh atau sebagian tubuh organisme, populasi, atau komunitas. Biomassa tumbuhan merupakan
Penelitian ini dilakukan di daerah Parongpong, Kabupaten Bandung Barat, dengan menggunakan 
rancangan acak kelompok (RAK) pola faktorial yang terdiri dari dua faktor, yaitu rasio limbah batubara (\% berat) dan dosis kompos (gram/pot). Rasio limbah batubara terdiri dari 6 (enam) perlakuan yaitu $0 \%$ (A0), 10\% (A1), 20\% (A2), $30 \%$ (A3), 40\% (A4) dan 50\% (A5). Dosis kompos terdiri dari 3 (tiga) perlakuan yaitu 0 gram/pot (K0), 400 gram/pot (K1) dan 800 gram/pot (K2). Total kombinasi perlakuan adalah 18 satuan dengan dua kali ulangan sehingga seluruhnya ada 36 satuan percobaan.

Penelitian penanaman bunga matahari pada media tanam dilakukan dibawah naungan (kanopi) sederhana, sehingga terlindung dari siraman air hujan secara langsung tetapi tetap mendapatkan penyinaran matahari secara langsung pada waktu pagi hari. Bunga matahari ditanam dalam pot plastik (polybag) yang berisi media tanam sebanyak $4 \mathrm{~kg} /$ pot yang merupakan kombinasi dari tanah, limbah batubara dan kompos sesuai perlakuan masing-masing (Gambar 1). Pemanenan tanaman dilakukan 10 minggu setelah tanam (MST) untuk kemudian dilakukan pemilahan bagian tanaman menjadi 3 bagian yaitu akar, batang dan daun serta bunga (Gambar 2). Analisis laboratorium dilakukan di Balai Penelitian Tanah dan Laboratorium B3 Teknik Lingkungan, ITB. perbedaan antar perlakuan pada masing-masing faktor perlakuan penelitian dilakukan uji lanjut dengan menggunakan uji jarak berganda Duncan, pada taraf ketelitian 5\% dengan menggunakan program SPSS.

\section{HASIL DAN PEMBAHASAN}

\section{Sifat Fisik dan Kimia Tanah}

Hasil analisis sifat fisik dan kimia tanah Balitsa Lembang disajikan pada Tabel 1 . Hasil análisis menunjukkan bahwa tanah Balitsa memiliki tekstur lempung dengan $\mathrm{pH}$ yang agak masam yaitu sebesar 5,6 $\left(\mathrm{H}_{2} \mathrm{O}\right)$ dan 5,2 $(\mathrm{KCl})$. Perbedaan nilai $\mathrm{pH} \mathrm{H}_{2} \mathrm{O}$ dengan $\mathrm{pH} \mathrm{KCl}$ pada pengukuran merupakan $\mathrm{pH}$ cadangan yang memiliki muatan positif yang cukup berarti untuk anion namun tidak berarti untuk kation. Kandungan Corganikdan N-total pada tanah Balitsa, Lembang termasuk kategori sedang yaitu masing-masing sebesar $2,53 \%$ dan $0,31 \%$, sedangkan rasio $\mathrm{C} / \mathrm{N}$ pada tanah termasuk kriteria rendah yaitu sebesar 8. Sementara itu, kandungan $\mathrm{P}$ tersedia pada tanah termasuk kriteria sangat tinggi yaitu sebesar $32 \mathrm{ppm}$. Kandungan kation $\mathrm{Ca}, \mathrm{K}$ dan Mg pada tanah ini tinggi yaitu masing-masing sebesar $28,73 \mathrm{me} / 100 \mathrm{~g}, 0,83 \mathrm{me} / 100 \mathrm{~g}$ dan 3,19 $\mathrm{me} / \mathrm{g}$. Hal ini berkorelasi dengan hasil analisa

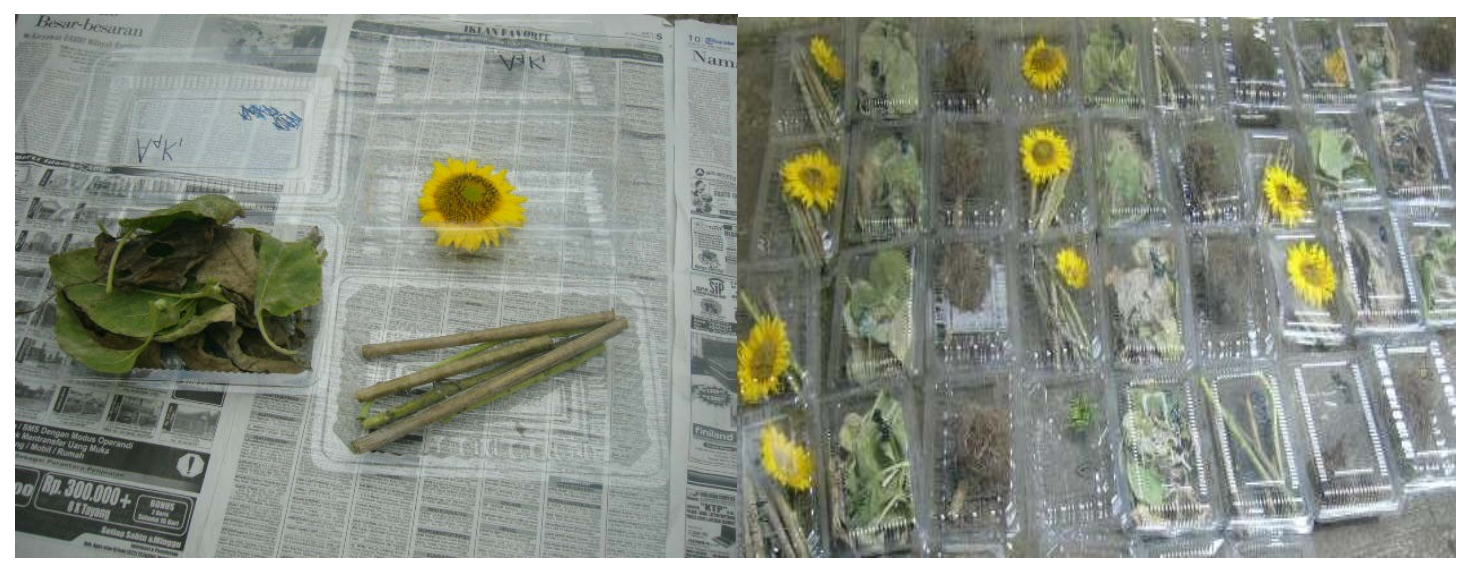

Gambar 2. Pemanenan dan Pemilahan Bagian Tanaman Bunga Matahari.

Analisa berat kering (bk) biomassa tanaman dilakukan dengan memanaskan sampel dalam oven $105^{\circ} \mathrm{C}$ sampai beratnya konstan. Pengaruh perbedaan perlakuan pada percobaan diuji dengan uji ANOVA (analysis of varian) pada taraf 5\%. Sementara, untuk mengetahui persentase kejenuhan basa yang tinggi yaitu sebesar $>100 \%$. Kapasitas tukar kation tanah termasuk kategori rendah yaitu sebesar 6,12 $\mathrm{meq} / 100 \mathrm{~g}$. 
Tabel. 1. Hasil analisis sifat fisik dan kimia tanah dan limbah batubara.

\begin{tabular}{|c|c|c|c|c|c|c|c|}
\hline \multirow{2}{*}{\multicolumn{2}{|c|}{ Parameter }} & \multirow{3}{*}{$\begin{array}{c}\text { Satuan } \\
\%\end{array}$} & \multirow{3}{*}{$\begin{array}{c}\begin{array}{c}\text { Tanah } \\
\text { Lembang }\end{array} \\
36,82\end{array}$} & \multirow{3}{*}{$\begin{array}{c}\begin{array}{c}\text { Limbah } \\
\text { Batubara }\end{array} \\
17,8\end{array}$} & \multicolumn{3}{|c|}{ Kriteria*) } \\
\hline & & & & & \multirow{2}{*}{$\begin{array}{c}\text { Rendah } \\
-\end{array}$} & \multirow{2}{*}{$\begin{array}{c}\text { Sedang } \\
-\end{array}$} & \multirow{2}{*}{$\begin{array}{c}\text { Tinggi } \\
-\end{array}$} \\
\hline Kadar air & & & & & & & \\
\hline \multirow[t]{3}{*}{ Tekstur } & Pasir & \multirow{3}{*}{$\%$} & 39 & 66 & & & \\
\hline & Debu & & 34 & 21 & & & \\
\hline & Liat & & 27 & 13 & & & \\
\hline \multirow{3}{*}{$\begin{array}{l}\text { Bahan } \\
\text { Organik }\end{array}$} & $\mathrm{C}$ & \multirow[t]{2}{*}{$\%$} & 2,53 & 2,78 & $1-2$ & $2,01-3,0$ & $3,01-5,00$ \\
\hline & $\mathrm{N}$ & & 0,31 & 0,24 & $0,1-0,2$ & $0,21-0,5$ & $0,51-0,75$ \\
\hline & $\mathrm{C} / \mathrm{N}$ & & 8 & 12 & $5-10$ & $11-14$ & $16-25$ \\
\hline $\mathrm{P}_{2} \mathrm{O}_{5}$ Olsen & & ppm & 32 & 25 & $5-10$ & $11-15$ & $16-20$ \\
\hline $\mathrm{K}_{2} \mathrm{O}$ & & ppm & 27 & 78 & $10-20$ & $21-40$ & $41-60$ \\
\hline \multirow[t]{4}{*}{ Nilai tukar Kation } & $\mathrm{Ca}$ & \multirow{4}{*}{$\mathrm{meq} / 100 \mathrm{~g}$} & 6,92 & 26,68 & $2-5$ & $6-10$ & $11-20$ \\
\hline & $\mathrm{Mg}$ & & 0,87 & 7,66 & $0,4-1,0$ & $1,1-2,0$ & $2,1-5,0$ \\
\hline & $\mathrm{K}$ & & 0,05 & 0,15 & $0,1-0,3$ & $0,4-0,5$ & $0,6-1,0$ \\
\hline & $\mathrm{Na}$ & & 0,13 & 0,87 & $0,1-0,3$ & $0,4-0,7$ & $0,8-1,0$ \\
\hline KTK & & $\mathrm{meq} / 100 \mathrm{~g}$ & 6,12 & 20,74 & $5-16$ & $17-24$ & $25-40$ \\
\hline \multirow[t]{2}{*}{ Kejenuhan Basa } & & $\%$ & $>100$ & $>100$ & $20-40$ & $40-60$ & $61-80$ \\
\hline & & & & & Masam & Netral & Alkalis \\
\hline \multirow[t]{2}{*}{$\mathrm{pH}$} & $\mathrm{H}_{2} \mathrm{O}$ & & 5,6 & 7,9 & $4,5-5,5$ & $6,5-7,5$ & $>8,5$ \\
\hline & $\mathrm{KCl}$ & & 5,2 & 7,6 & - & - & - \\
\hline
\end{tabular}

*) Pusat Penelitian Tanah, 1983 (dalam Sarief, 1984)

\section{Sifat Fisik dan Kimia Limbah Batubara}

Hasil analisa terhadap limbah batubara menunjukkan bahwa limbah batubara memiliki $\mathrm{pH}$ yang alkalis yaitu sebesar 7,9 $\left(\mathrm{H}_{2} \mathrm{O}\right)$ dan 7,6 $(\mathrm{KCl})$. Kandungan $\mathrm{C}$-organik dan $\mathrm{N}$-total pada limbah batubara, termasuk kategori sedang yaitu masing-masing sebesar $2,78 \%$ dan $0,24 \%$, sedangkan rasio $\mathrm{C} / \mathrm{N}$ pada limbah batubara termasuk kriteria tinggi yaitu sebesar 12 . Sementara itu, kandungan $P$ tersedia pada limbah batubara termasuk kriteria sangat tinggi yaitu sebesar 25 ppm. Kandungan kation $\mathrm{Ca}, \mathrm{Mg}$ dan $\mathrm{Na}$ pada limbah batubara yang digunakan termasuk kriteria tinggi yaitu masing-masing sebesar $26,68 \mathrm{me} / 100 \mathrm{~g}, 7,6 \mathrm{me} / 100 \mathrm{~g}$ dan 0,87 me/g. Kapasitas tukar kation (KTK) pada limbah batubara termasuk kriteria sedang yaitu sebesar $20,74 \mathrm{meq} / 100 \mathrm{~g}$.

Hasil analisa logam berat total pada limbah batubara disajikan pada Tabel 2. Hasil analisa menunjukkan bahwa konsentrasi logam berat $\mathrm{Cu}$ dan $\mathrm{Pb}$ pada limbah batubara masing-masing sebesar $27,41 \mathrm{mg} / \mathrm{kg}$ dan $54,26 \mathrm{mg} / \mathrm{kg}$, namun masih berada dibawah batas maksimum baku mutu kolom A dan B berdasarkan Keputusan Kepala Bapedal No.04/Bapedal/IX/1995 tentang tata cara persyaratan penimbunan hasil pengolahan, persyaratan lokasi bekas pengolahan dan lokasi bekas penimbunan limbah bahan berbahaya dan beracun. Sementara itu, konsentrasi logam $\mathrm{Cd}$ dan $\mathrm{Zn}$ masing-masing sebesar $5,35 \mathrm{mg} / \mathrm{kg}$ dan $832,87 \mathrm{mg} / \mathrm{kg}$ atau berada diatas baku mutu kolom $\mathrm{B}$, namun masih berada dibawah baku mutu kolom A.

\section{Sifat Fisik dan Kimia Kompos}

Hasil analisis laboratorium terhadap sifat fisik dan kimia kompos yang digunakan pada penelitian (Tabel 3), menunjukkan bahwa kompos yang digunakan pada penelitian ini memiliki kadar air (persen berat) dan $\mathrm{pH}$ diatas standar maksimum SNI (Badan Standarisasi Nasional, 2004), yaitu masing-masing sebesar $52,73 \%$ dan 7,63 . Kandungan $\mathrm{C}$ pada kompos sebesar $8,21 \%$ atau tidak memenuhi standar minimum SNI yaitu sebesar 9,80\%. Sementara itu, kandungan $\mathrm{N}$ dan rasio $\mathrm{C} / \mathrm{N}$ pada masingmasing sebesar $0,44 \%$ dan 14 atau memenuhi standar minimum SNI yaitu sebesar 0,4\% dan 10 . 
Tabel 2. Hasil Analisa Konsentrasi Logam Berat Pada Limbah Batubara.

\begin{tabular}{|c|c|c|c|c|}
\hline \multirow{2}{*}{ No. } & \multirow{2}{*}{ Parameter } & \multirow{2}{*}{$\begin{array}{c}\text { Hasil Analisa } \\
(\mathrm{mg} / \mathrm{kg})\end{array}$} & \multicolumn{2}{|c|}{ Baku Mutu* $(\mathrm{mg} / \mathrm{kg})$} \\
\cline { 4 - 5 } & & 5,35 & 50 & 5 \\
\hline 1 & Kadmiun $(\mathrm{Cd})$ & 832,87 & 5000 & 500 \\
\hline 2 & Seng $(\mathrm{Zn})$ & 27,41 & 1000 & 100 \\
\hline 3 & Tembaga $(\mathrm{Cu})$ & 54,26 & 3000 & 300 \\
\hline 4 & Timbal $(\mathrm{Pb})$ & & & \\
\hline
\end{tabular}

*) Kep.Kepala Bapedal No.04/Bapedal/IX/1995

Kandungan $\mathrm{P}_{2} \mathrm{O}_{5}$ pada kompos sebesar $0,22 \%$ atau memenuhi standar minimum SNI, sementara kandungan $\mathrm{K}_{2} \mathrm{O}$ sebesar 0,4 atau berada dibawah standar minimum SNI. Kandungan $\mathrm{Ca}$ dan $\mathrm{Mg}$ pada kompos masing-masing sebesar $1,41 \%$ dan $0,33 \%$ atau memenuhi standar maksimum SNI.

\section{Biomassa Tanaman Bunga Matahari}

\section{Akar}

Pengaruh penambahan limbah batubara dan kompos terhadap rata-rata berat kering biomassa bagian akar tanaman bunga matahari ditampilkan pada grafik dalam Gambar 3. Grafik tersebut memperlihatkan bahwa penambahan rasio limbah batubara dan dosis kompos akanmeningkatkan rata-rata berat kering (bk) biomassa akar tanaman matahari. Hal tersebut tidak berlaku pada kombinasi perlakuan penambahan limbah batubara $50 \%$ dan dosis kompos $0 \mathrm{~kg} /$ pot (A5K0) dimana biomassanya menurun. Berat kering (bk) biomassa tertinggi adalah akar tanaman bunga matahari yang ditanam pada tanah yang ditambahkan kombinasi perlakuan 50\% limbah batubara dan 800 gram dosis kompos (A5K2), yaitu sebesar $0,0349 \mathrm{~kg}$ berat kering (bk). Ratarata biomassa (bk) terendah adalah bagian akar tanaman yang ditanam pada tanah yang ditambah dengan kombinasi perlakuan $0 \%$ limbah batubara dan tanpa penambahan kompos (A0K0) yaitu sebesar $0,0102 \mathrm{~kg}$ (bk).

Tabel 3. Hasil Analisis Sifat Fisik dan Kimia Kompos.

\begin{tabular}{|c|c|c|c|c|c|}
\hline \multirow{2}{*}{\multicolumn{2}{|c|}{ Parameter }} & \multirow{3}{*}{$\begin{array}{c}\text { Satuan } \\
\%\end{array}$} & \multirow{3}{*}{$\begin{array}{c}\begin{array}{c}\text { Hasil } \\
\text { Analisa }\end{array} \\
52,73\end{array}$} & \multicolumn{2}{|c|}{ Standar*) } \\
\hline & & & & \multirow{2}{*}{$\frac{\text { Minimum }}{-}$} & \multirow{2}{*}{$\frac{\text { Maksimum }}{50}$} \\
\hline Kadar air & & & & & \\
\hline \multirow[t]{2}{*}{$\mathrm{pH}$} & $\mathrm{H}_{2} \mathrm{O}$ & & 7,63 & \multirow[t]{2}{*}{6,80} & \multirow[t]{2}{*}{7,49} \\
\hline & $\mathrm{KCl}$ & & 7,57 & & \\
\hline \multirow{3}{*}{$\begin{array}{l}\text { Bahan } \\
\text { Organik }\end{array}$} & C - Org & \multirow[t]{2}{*}{$\%$} & 8,21 & 9,80 & 32 \\
\hline & $\mathrm{N}$ total & & 0,44 & 0,40 & - \\
\hline & $\mathrm{C} / \mathrm{N}$ & & 14 & 10 & 20 \\
\hline $\mathrm{P}_{2} \mathrm{O}_{5}$ & & $\%$ & 0,22 & 0,10 & - \\
\hline $\mathrm{K}_{2} \mathrm{O}$ & & $\%$ & 0,04 & 0,20 & - \\
\hline $\mathrm{CaO}$ & & $\%$ & 1,41 & $* *$ & 25,50 \\
\hline $\mathrm{MgO}$ & & $\%$ & 0,33 & $* *$ & 0,60 \\
\hline $\mathrm{Na}$ & & $\%$ & 0,05 & - & - \\
\hline
\end{tabular}

*) Standar kualitas kompos SNI 19-7030-2004(Badan Standarisasi Nasional, 2004) 


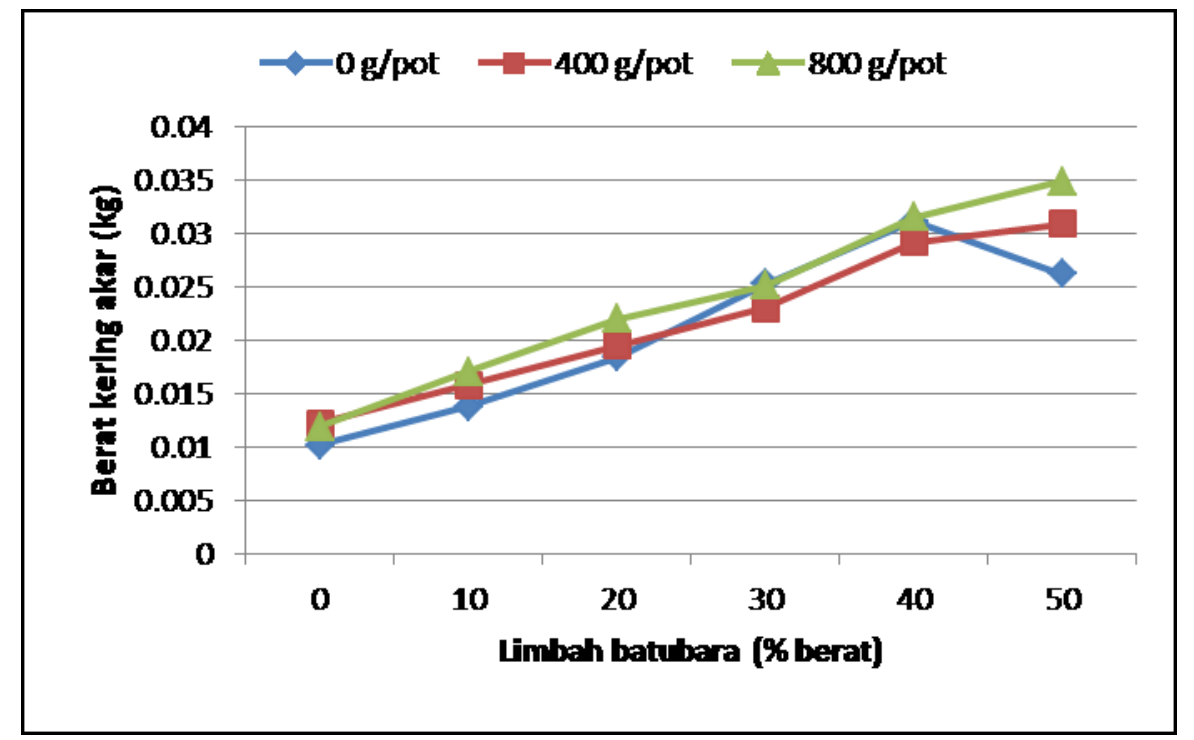

Gambar 3.Grafik pengaruh rasio limbah batubara dan dosis kompos terhadap rata-rata biomassa bagian akar tanaman bunga matahari.

\section{Batang dan Daun}

Pengaruh penambahan limbah batubara dan kompos terhadap rata-rata biomassa bagian batang dan daun (bk) tanaman bunga matahari ditunjukkan pada grafik dalam Gambar 4. Gambar tersebut memperlihatkan bahwa penambahan limbah batubara dan dosis kompos meningkatkan rata-rata biomassa (bk) bagian batang dan daun, kecuali pada kombinasi perlakuan $30 \%$ limbah batubara dan $400 \mathrm{~g} / \mathrm{pot}$ kompos (A3K1) serta perlakuan 50\% limbah batubara dan tanpa penambahan kompos (A5K0) dimana terjadi penurunan. Rata-rata biomassa (bk) tertinggi adalah bagian batang dan daun tanaman bunga matahari yang ditanam pada tanah dengan penambahan kombinasi perlakuan $50 \%$ limbah batubara dan 800 gram kompos (A5K2), yaitu sebesar $0,0673 \mathrm{~kg}$ berat kering. Rata-rata biomassa terendah adalah bagian batang dan daun tanaman bunga matahari yang ditanam pada tanah tanpa penambahan limbah

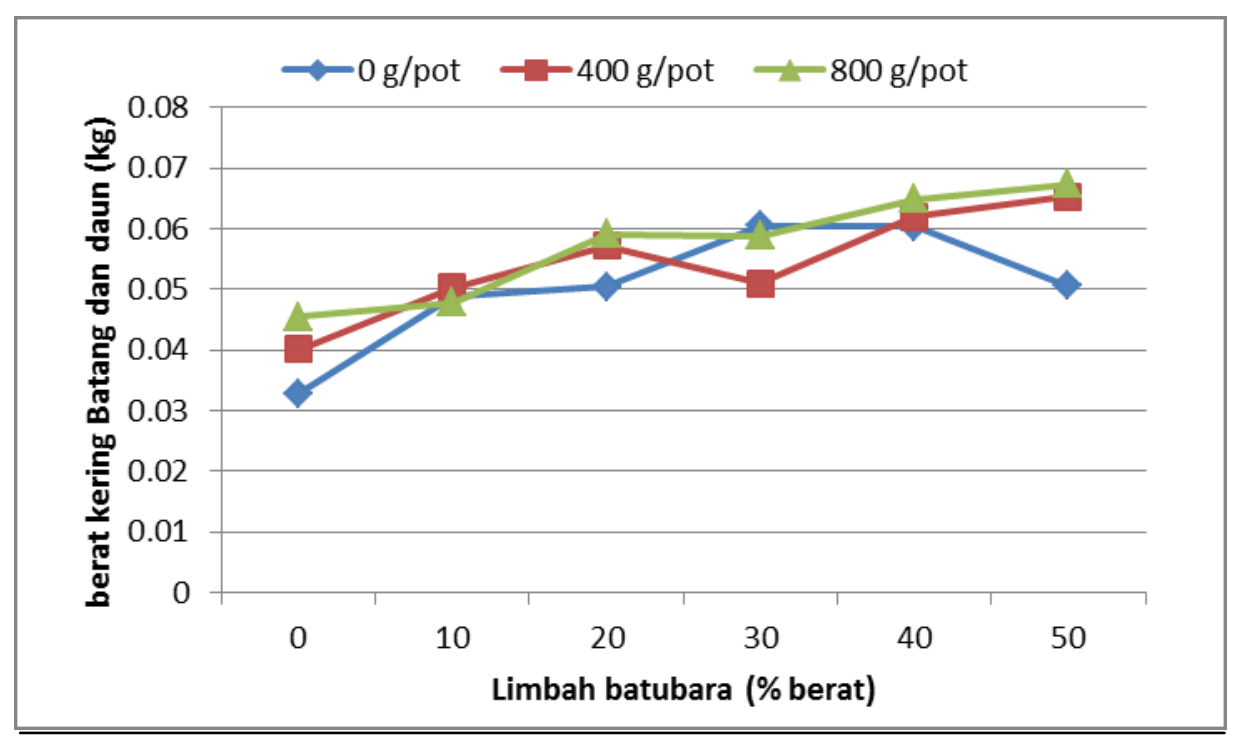

Gambar4.Grafik pengaruh penambahan limbah batubara dan kompos terhadap ratarata biomassa bagian batang dan daun tanaman bunga matahari. 
batubara dan kompos (A0K0) yaitu sebesar $0,0328 \mathrm{~kg}$ berat kering.

\section{Batang}

Gambar 5 menunjukkan grafik pengaruh penambahan limbah batubara dan kompos terhadap rata-rata biomassa (bk) bagian bunga tanaman bunga matahari.Grafik tersebut menunjukkan bahwa penambahan rata-rata biomassa (bk) tertinggi terdapat pada bagian bunga yang ditanam pada tanah dengan penambahan kombinasi perlakuan 50\% limbah batubara dan 800 gram kompos, (A5K2) yaitu sebesar $0,0321 \mathrm{~kg}$ berat kering (bk). Rata-rata biomassa (bk) bunga terendah terdapat pada tanaman bunga matahari yang ditanam pada tanah tanpa penambahan limbah batubara dan kompos (A0K0) yaitu sebesar 0,0113 kg (bk). sebesar $0,1826 \mathrm{~kg}$. Rata-rata berat kering biomassa terendah terdapat pada tanaman bunga matahari yang ditanam pada tanah dengan penambahan kombinasi perlakuan $0 \%$ limbah batubara dan tanpa penambahan kompos (A0K0) yaitu sebesar $0,0965 \mathrm{~kg}$. Berat kering biomassa tertinggi terdapat pada bagian batang dan daun tanaman yaitu sebesar $0,0673 \mathrm{~kg}$, sedangkan berat kering biomassa terendah terdapat pada bagian bunga tanaman bunga matahari yaitu sebesar $0,0113 \mathrm{~kg}$.

\section{Pengaruh penambahan limbah batubara dan kompos}

Hasil analisis statistik datapengaruh penambahan limbah batubara dan kompos terhadap berat kering biomassa tanaman bunga matahari dapat dilihat pada Tabel 4. Berdasarkan tabel analisis

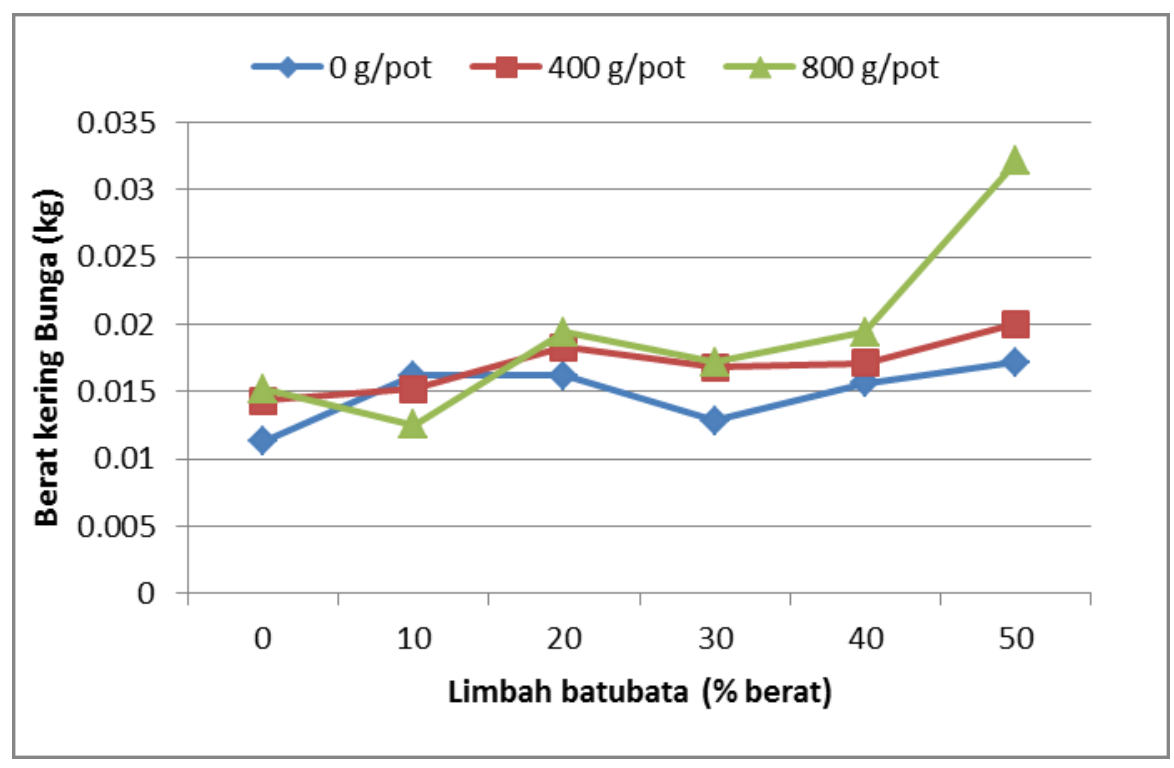

Gambar 5.Grafik pengaruh penambahan limbah batubara dan kompos terhadap rata-rata biomassa bagian bunga tanaman bunga matahari.

\section{Total Biomassa Tanaman}

Gambar 6 adalah grafik pengaruh penambahan limbah batubara dan kompos terhadap rata-rata berat kering biomassa tanaman bunga matahari. Grafik tersebut memperlihatkan rata-rata berat biomassa tertinggi terdapat pada tanaman bunga matahari yang ditanam pada tanah dengan penambahan kombinasi perlakuan $50 \%$ limbah batubara dan 800 gram kompos (A5K2), yaitu ragam, diperoleh nilai $\mathrm{F}$ hitung $(0,999)$ lebih besar dari $F$ tabel $(0,481)$, sehingga dapat disimpulkan bahwa penambahan limbah batubara dan kompos pada tanah berpengaruh nyata terhadap biomassa tanaman bunga matahari.

Hasil uji Duncan untuk menganalisa pengaruh perlakuan penambahan limbah batubara dan kompos terhadap biomassa tanaman bunga matahari dapat dilihat pada Tabel 5 dan Tabel 6 . Hasil uji Duncan menunjukkan penambahan 


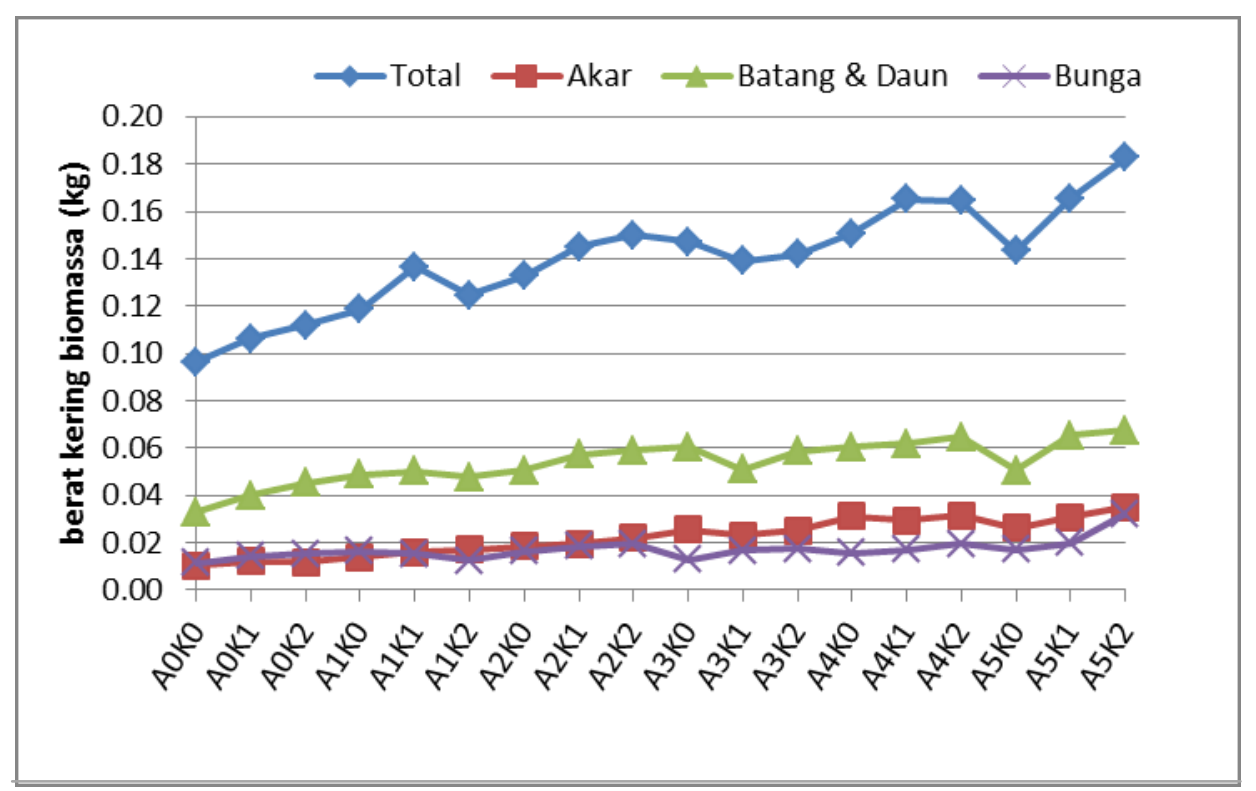

Gambar 6. Grafik pengaruh rasio batubara dan dosis kompos terhadap berat kering biomassa tanaman bunga matahari.

limbah batubara 50\% (\% berat) menghasilkan biomassa tanaman tertinggi namun tidak berbeda nyata dengan perlakuan penambahan limbah batubara $40 \%$. Sementara itu, dari Tabel 5 dapat dilihat bahwa biomassa yang dihasilkan perlakuan penambahan kompos $400 \mathrm{~g} /$ pot tidak berbeda nyata dengan penambahan kompos 800 g/pot.
Limbah batubara memiliki $\mathrm{pH}$ alkalin, unsur hara baik makro maupun mikro, dan ukuran yang halus. Hal ini menyebabkan limbah batubara dapat dimanfaatkan untuk meningkatkan $\mathrm{pH}$, menambah kandungan unsur hara, meningkatkan struktur dan kapasitas kelembaban tanah. (Tripathy dkk., 2006)

Tabel 4. Analisis RagamPengaruh Rasio Limbah Batubara dan Dosis Kompos terhadap Biomassa (bk) Tanaman Bunga Matahari.

\begin{tabular}{|l|c|c|r|r|r|}
\hline \multicolumn{1}{|c|}{ Sumber Keragaman } & $\begin{array}{c}\text { Jumlah } \\
\text { Kuadrat }\end{array}$ & $\begin{array}{c}\text { Derajat } \\
\text { Bebas (df) }\end{array}$ & $\begin{array}{c}\text { Kuadrat } \\
\text { Tengah }\end{array}$ & F $_{\text {hitung }}$ & F0,5 \\
\hline Ulangan (R) &, 072 & 1 &, 072 & 510,579 &, 000 \\
Perlakuan &, 014 & 5 &, 003 & 20,505 &, 000 \\
$\quad$ Limbah batubara (L) &, 001 & 2 &, 001 & 4,946 &, 020 \\
$\quad$ Kompos (K) &, 001 & 10 &, 000 &, 999 &, 481 \\
L* K &, 002 & 17 &, 000 & & \\
Galat &, 798 & 36 & & & \\
Total & & & & & \\
\hline
\end{tabular}


Tabel 5. Hasil Uji Duncan Pengaruh Perlakuan Penambahan Limbah Batubara Terhadap Biomassa Tanaman Bunga Matahari.

\begin{tabular}{|c|r|r|r|r|r|}
\hline \multirow{2}{*}{ Rasio Limbah batubara } & \multirow{2}{*}{$\mathbf{N}$} & \multicolumn{4}{|c|}{ Perbedaan Rerata } \\
\cline { 3 - 6 } & & $\mathbf{1}$ & $\mathbf{2}$ & \multicolumn{1}{|c|}{$\mathbf{3}$} & \multicolumn{1}{|c|}{$\mathbf{4}$} \\
\hline A0 & 6 &, 104850 & & & \\
A1 & 6 & &, 126633 & & \\
A2 & 6 & & &, 142600 & \\
A3 & 6 & & &, 142667 & \\
A4 & 6 & & & &, 160117 \\
A5 & 6 & & & &, 163817 \\
Signifikan & & 1,000 & 1,000 &, 992 &, 596 \\
\hline
\end{tabular}

Tabel 6. Hasil Uji Duncan Pengaruh Perlakuan Penambahan Kompos Terhadap Biomassa Tanaman Bunga Matahari.

\begin{tabular}{|c|r|r|r|}
\hline \multirow{2}{*}{ Dosis Kompos } & \multirow{2}{*}{$\mathbf{N}$} & \multicolumn{2}{|c|}{ Perbedaan Rerata } \\
\cline { 3 - 4 } & & $\mathbf{1}$ & \multicolumn{1}{c|}{$\mathbf{1}$} \\
\hline K0 & 12 &, 131492 & \\
K1 & 12 & &, 142967 \\
K2 & 12 & &, 145883 \\
Signifikan & & 1,000 &, 555 \\
\hline
\end{tabular}

Reaksi tanah (pH) sangat mempengaruhi ketersediaan unsur hara tanah bagi tanaman. Kemasaman atau $\mathrm{pH}$ tanah adalah salah satu dari beberapa indikator kesuburan tanah. Pada reaksi tanah yang netral, unsur hara tersedia dalam jumlah yang cukup banyak (optimal), sedangkan pada $\mathrm{pH}$ tanah kurang dari 6,0 ketersediaan unsur-unsur fosfor, kalium, belerang, kalsium, magnesium dan molibdinum menurun dengan cepat.

Penambahan limbah batubara pada tanah dapat meningkatkan $\mathrm{pH}$, terutama pada tanah masam daripada tanah yang cenderung basa karena $\mathrm{CO}_{2}$ akan bereaksi lebih reaktif dengan $\mathrm{CaO}$ menghasilkan $\mathrm{CaCO}_{3}$ sehingga $\mathrm{pH}$ tanah cenderung menjadi netral (Thivahary, 2004).

Kemasaman tanah juga mempengaruhi pertumbuhan akar. Nilai $\mathrm{pH}$ tanah dengan kisaran
5-8 berpengaruh langsung pada pertumbuhan akar. Meskipun masing-masing tanaman menghendaki kisaran $\mathrm{pH}$ tertentu, tetapi kebanyakan tanaman tidak dapat hidup pada $\mathrm{pH}$ yang sangat rendah (di bawah 4) dan sangat tinggi (di atas 9). Keasaman tanah juga menentukan kelakuan dari unsur-unsur hara tertentu, karena $\mathrm{pH}$ dapat mengendapkan atau membuat unsur hara tersedia (Islami dan Utomo, 1995).

Limbah batubara memiliki nilai Kapasitas tukar kation (KTK) yang tinggi, disebabkan limbah batubara mengandung kation-kation basa yang dapat dipertukarkan seperti $\mathrm{Ca}^{2+}, \mathrm{Mg}^{2+}, \mathrm{Na}^{+}$, dan $\mathrm{Al}^{3}$, yang terikat dalam komplek serapan.

Kapasitas Tukar Kation (KTK) merupakan sifat kimia yang sangat erat hubungannya dengan kesuburan tanah.Tanah dengan KTK tinggi 
mampu menyerap, menyimpan dan menyediakan unsur hara bagi tanaman. Tanah yang memiliki KTK tinggi menyebabkan unsur-unsur hara tersebut terikat pada kompleks jerapan koloid sehingga tidak mudah tercuci.

Peningkatan $\mathrm{pH}$ dan KTK tanah oleh penambahan limbah batubara merupakan proses yang bersifat sementara. Hal ini disebabkan karena $\mathrm{pH}$ tanah dipengaruhi oleh faktor kejenuhan basa, sifat koloid organik dan penyerapan kation oleh koloid tanah.Penyerapan unsur-unsur hara yang termasuk kation basa seperti $\mathrm{Ca}^{2+}, \mathrm{Mg}^{2+}, \mathrm{Na}^{+}, \mathrm{K}^{+}$, dan $\mathrm{Al}^{3+}$ dari tanah oleh tanaman bunga matahari dapat menyebabkan penurunan $\mathrm{pH}$ tanah. Sementara itu, KTK tanah dipengaruhi oleh sifat dan unsur tanah itu sendiri antara lain adalah reaksi tanah atau $\mathrm{pH}$, tekstur tanah atau jumlah liat, jenis mineral tanah, bahan unsur serta pengapuran dan pemupukan.

\section{KESIMPULAN}

Berdasarkan hasil penelitian dapat ditarik kesimpulan bahwa penambahan limbah batubara pada tanah berpengaruh terhadap biomassa tanaman bunga matahari. Semakin besar penambahan limbah batubara pada tanah, biomassa tanaman bunga matahari semakin meningkat. Biomassa tertinggi dihasilkan tanaman bunga matahari yang ditanam pada tanah yang ditambahkan 50\% limbah batubara yaitu sebesar 0,16 kg. Dari penelitian ini juga tampak bahwa semakin besar penambahan dosis kompos pada tanah, biomassa tanaman bunga matahari semakin meningkat. Biomassa tertinggi dihasilkan tanaman bunga matahari yang ditanam pada tanah yang ditambahkan kompos sebanyak $800 \mathrm{gram} /$ pot yaitu sebesar $0,14 \mathrm{~kg}$. Sedangkan kombinasi perlakuan limbah batubara dengan kompos berpengaruh terhadap biomassa tanaman bunga matahari yang dihasilkan. Biomassa bunga matahari tertinggi dihasilkan oleh kombinasi perlakuan $50 \%$ limbah batubara dan $800 \mathrm{gr} /$ pot kompos yaitu sebesar $0,1826 \mathrm{~kg}$.

\section{DAFTAR PUSTAKA}

Adriano, D. C., Page, A. L, Elseewi, A. A, Chang, A.C, dan Straugham, I., 1980. Utilization and disposal of fly-ash and coal residues in terrestrial ecosystem: A review. Journal Enviromental. Quality, 9, 333-344.

Badan Standarisasi Nasional, 2004. Spesifikasi Kompos dari Sampah Organik Domestik. SNI No. 19-7030-2004.

Bisnis Indonesia online, 2012. Ekspor Batubara Boleh Sepanjang Kebutuhan Domestik Terpenuhi. http://www.bisnis.com/articles. Diunduh pada 4 Juni 2012.

Damayanti, R., 2003. Pemanfaatan Abu Batubara Sebagai Bahan Pembenah Tanah atau Soil Conditioner di Daerah Penimbunan Tailing Pengolahan Emas. Puslitbang Teknologi Mineral dan Batubara, Departemen Energi dan Sumber Daya Mineral.

Evangelou, V. P., 1996. Coal Ash Chemical Properties and Potential Influence on Water Quality. Proceedings of Coal Combustion By-Products Associated with Coal Mining: Interactive Forum. Southern Illinois University at Carbondale.

Hamilton, L. S. dan King, H. L. M. N., 1988. Daerah Aliran Sungai Hutan Tropika. Diterjemahkan oleh Krisnawati Suryanata. UGM Press. Yogyakarta.

Islami, T dan Utomo, W. H., 1995. Hubungan Tanah, Air dan Tanaman. IKIP Semarang Press

Marques A. P., Oliveira R. S., Rangel A. O., dan Castro P. M., 2008. Application of manure and compost to contaminated soils and its effect on zinc accumulation by Solanum nigrum inoculated with arbuscular mycorrhizal fungi. Enviromental Pollution, $151,608-620$.

Pramudya, A. S., 2007. Pengaruh Penambahan EDTA, Asam Humat dan Asam Fulvat dalam Fitoremediasi Tanah Terkontaminasi Logam Nikel, Arsen dan Merkuri oleh Bunga Matahari (Helianthus Annuus). Tesis Master (S2). Jurusan Teknik Lingkungan, Institut Teknologi Bandung. 
Rotkittikhun, P., Chaiyarat, R., Kruatreehue, M., Pokethitiyook, P., and Baker, A., 2007. Growth and lead accumulation by grasses Vetiveria zizanioides and Thysanolaenamaxima in lead-contaminated soil amended with pig manure and fertilizer: A glasshouse study. Chemosphere, 66, 45-53.

Pikiran Rakyat Online, 2012. Limbah Batu Bara di Jabar Meningkat. http://www.pikiran rakyat online.co.id. Diunduh pada 9 Januari 2012.

Sarief, S., 1984. Kesuburan dan Pemupukan Tanah Pertanian. Pustaka Buana. Bandung

Sutomo, A., dan Sofyan, A., 2008. Pemanfaatan Limbah Padat Hasil Pembakaran Batubara untuk Beton Keramik. Prosiding Lokakarya Peran Litbang Bidang Kebumian Bagi Pembangunan Daerah Jawa Barat Selatan. UPT. Jampang KulonLIPI.

Suyartono, 2004. Hidup dengan Batubara, Dari Kebijakan Hingga Pemanfaatan. Edisi Kedua. Yayasan Media Bakti Tambang. Mutiara Bumi, Jakarta
Thivahary, V., 2004. Fly ash-A potential soil amendment for increasing crop yields. Daily News, 17 Februari 2004. (http://www.dailynews.lk/2004/02/17/fea0. html, diunduh pada 20 Februari 2013).

Tripathy S., Bhattacharyya P., Chakrabdorty A., Chakrabarti and Powell M. A., 2006. Copper and Zinc Uptake by Rice and Accumulation in Soil Amended with Municipal Solid Waste Compost. Environmental Geology, 49 (7), 10641070.

Wardani, S. P. R., 2008. Pemanfaatan Limbah Batubara (Fly ash) Untuk Stabilisasi Tanah Maupun Keperluan Teknik Sipil Lainnya Dalam Mengurangi Pencemaran Lingkungan. Pidato Pengukuhan Guru Besar. Jurusan Teknik Geologi, Fakultas Teknik, Universitas Diponegoro, Semarang.

Wong, J. W. C. dan Su, D.C., 1997. Reutilization Of Coal Ash And Sewage Sludge As An Artificial Soil Mix: Effect of PreIncubation on Soil Physico-Chemical Properties. Bioresource Technology, Vol. 59, 97-102. 